\title{
Blessing Or Curse? Community Banks' Use Of Federal Home Loan Bank Advances
}

John R. Hall, (E-mail: jrhall1@ualr.edu), University of Arkansas, Little Rock

\begin{abstract}
Banks enjoyed record profitability during the nineties, as the economy grew and loan demand followed. Deposit growth did not keep pace so many banks sought alternative funding, including Federal Home Loan Bank advances which have potential risk-increasing incentives. The results show that advance-using banks operate with much higher levels of loans to assets, much lower levels of capital, and extend commitments for future lending at a greater rate than banks that do not use advances. A logistic regression finds high loans, and low deposits and equity (all as a percent of assets) are key predictors of FHLB advance use. Also, for the banks examined, there is a concentration of advance users among the banks with the lowest capital and highest levels of non-performing loans. These results offer insight for future research as well as focus for supervisory scrutiny of FHLB advance-using banks.
\end{abstract}

\section{INTRODUCTION}

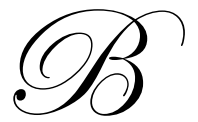

anks across the country enjoyed record profitability during the nineties, and these strong results occurred at banks of all sizes. As the economy grew, loan demand grew. However, deposit growth did not always keep pace. With the surging stock market, investors increasingly viewed bank deposits as unattractive alternatives. If loan demand was growing but deposit growth did not keep pace, how were banks to fill the funding gap? Increasingly, banks turned to advances from the Federal Home Loan Bank. From 1992 to 1999, the number of FDIC-defined community banks (those with assets less than $\$ 500$ million) that are members of the FHLB grew from under 1200 to nearly 5000 , with advances growing from about $\$ 1.6$ billion to over $\$ 25$ billion. ${ }^{1}$

The tremendous growth in banks' use of FHLB advances raises concerns with the banking system's regulators. The FDIC now reports on the use of these advances in its Quarterly Banking Profile, and banks must disclose use of advances in their regular Reports of Condition (call reports). If these advances are coming from a federal agency, and banks are using them to fill loan demand not met by deposit availability, then why should anyone be concerned? Three related issues drive the increased focus on banks' use of the advances: (1) asset growth more rapid than deposit growth would support, (2) increased risk without the imposition of risk pricing, and (3) increased costs to the FDIC in failure resolutions.

Rapid growth and increased risk are closely related, and the nature of FHLB advances coupled with these two points creates the potential for the third concern. That is, without access to the advances, banks would have to limit asset growth to deposit growth or use other borrowed funds like jumbo CDs. These funding sources would cause the bank to pay market rates related to risk, because the jumbo CDs are uninsured. ${ }^{2}$ Using advances bypasses this brake on growth, and because there is no risk premium on advanced funds, also eliminates any increasing cost of risk to the banker. The FHLB is able to advance funds without risk premia because its debt is backed (implicitly) by the federal government and it secures the advances with collateral (high quality loans in the bank's loan portfolio). This secured position is what creates the potential problem for the FDIC. Should a bank with advances outstanding get into financial difficulty resulting in FDIC action, the FHLB's position as a creditor is covered by the loans serving as collateral. Removing those pledged loans leaves a smaller pool of poorer quality assets for the FDIC, increasing its loss from the bank's failure. 
This paper looks at the financial characteristics of community banks to investigate these concerns. But what is a community bank? Usually the definition is a single-factor cut based on asset size, such as the FDIC's cap of $\$ 500$ million, but this need not be the only means of identifying these banks. Hannan and Prager (2001) alternatively define community banks as those that obtain at least 90 percent of their deposits in a single state (or more restrictively, in a single metropolitan statistical area). DeYoung, Hunter, and Udell (2003) provide a broader, functional definition: "a community bank holds a commercial bank or thrift charter; operates physical offices only within a limited geographic area; offers a variety of loan and checkable insured deposit accounts; and has a local focus that precludes its equity shares from trading in well-developed capital markets." The research in this paper uses the full set of Arkansas banks from 1996 to 2001 because virtually every bank satisfies all the definitions of a community bank offered above. The similarity of Arkansas banks to the national set of community banks is explored further below.

The remainder of the paper is organized as follows. Section II summarizes the Federal Home Loan Bank and sets the context for the research questions, and Section III provides evidence that Arkansas banks are representative of the national set of community banks. Section IV presents the empirical evidence regarding differences between banks using FHLB advances and those that do not, and Section V concludes.

\section{BANKS AND THE FHLB}

The Federal Home Loan Bank system was created in 1932 as a parallel to the Federal Reserve System, with a focus on "advancing" funds for mortgage lending by, and with membership restricted to, savings institutions. Prior to the growth of active secondary mortgage markets (enhanced by such government sponsored enterprises as GNMA and FNMA), a mortgage lender would have to warehouse or hold the loan for its entire life. This "lend and hold" relationship could lead to situations where potentially sound borrowers would be denied credit if the lender was unable to support the loan with deposits. The FHLB worked to break this connection by creating loans secured by mortgages already in the institution's loan portfolio, with the proceeds to be used to create new mortgages. The decline of the savings and loan industry and the shift of mortgage lending to other institutions like commercial banks led to changes in the scope of the FHLB. Banks were allowed to become members in 1989, and provisions of the Financial Services Modernization Act of 1999 expanded allowable collateral beyond mortgage loans to include commercial and agricultural loans. Now banks constitute the overwhelming majority of FHLB membership. As noted above, Arkansas banks have mirrored this trend, with 104 of 177 banks in the state having advances outstanding at the end of 2001.

\section{A FIRST LOOK AT THE DATA}

The structure of the U.S. banking industry grows more concentrated each year, yet there remains a large number of banks that can be termed community banks. The Arkansas banking environment offers an appealing set of data, because virtually every bank headquartered in the state satisfies any of the variety of community bank definitions identified above. Additionally the financial, organizational, and location characteristics of Arkansas banks are very similar to the distribution of all community banks. Table 1 provides a comparison of key measures between the set of all banks with assets less than $\$ 500$ million and all banks headquartered in Arkansas for the years 1996 to 2001 .

Evaluation of the data in Table 1 reveals that the average Arkansas bank is slightly larger than the average community bank nationally, is slightly more likely to be organized as a bank holding company, and is slightly less likely to be in a $\mathrm{MSA}^{3}$. Year by year patterns in loans, deposits, and equity as a percent of total assets are nearly identical for the Arkansas and national data. Two differences are notable, though not large: the average Arkansas bank holds more mortgages than the average community bank, and the average Arkansas bank is less profitable, as measured by ROA. Additionally, Arkansas banks have, like the national trend noted in the introduction, increased their use of FHLB advances: in Arkansas, banks with advances outstanding increased from 15 in 1992 to 107 in 2000, with $\$ 1.01$ billion in outstanding advances. The overall consistency in Table 1 and the increased use of FHLB advances suggest examining the behavior of Arkansas banks can shed light on U.S. community banks as well. 
Table 1:

Key Characteristics of U.S. Community Banks and Arkansas Banks 1996 to 2001

\begin{tabular}{|c|c|c|c|c|c|c|c|}
\hline & & 1996 & 1997 & 1998 & 1999 & 2000 & 2001 \\
\hline \multirow[t]{2}{*}{ Number } & All U.S. & 8853 & 8471 & 8103 & 7884 & 7614 & 7345 \\
\hline & Arkansas & 233 & 225 & 202 & 194 & 184 & 177 \\
\hline \multirow{2}{*}{$\begin{array}{l}\text { Bank Holding } \\
\text { Company (\%) }\end{array}$} & All U.S. & 75.89 & 77.03 & 77.79 & 78.13 & 78.22 & 78.98 \\
\hline & Arkansas & 89.70 & 89.33 & 90.10 & 90.21 & 89.13 & 91.01 \\
\hline \multirow{2}{*}{$\begin{array}{l}\text { Metro. Stat. } \\
\text { Area (\%) }\end{array}$} & All U.S. & 40.53 & 40.48 & 40.65 & 41.27 & 41.60 & 41.50 \\
\hline & Arkansas & 27.90 & 27.11 & 26.73 & 27.32 & 28.80 & 27.53 \\
\hline \multirow{2}{*}{$\begin{array}{l}\text { Total Assets, } \\
\text { Average (\$000) }\end{array}$} & All U.S. & 90,806 & 92,633 & 97,460 & 100,250 & 104,571 & 110,760 \\
\hline & Arkansas & 127,078 & 123,006 & 117,554 & 133,317 & 132,889 & 149,915 \\
\hline \multirow{2}{*}{$\begin{array}{l}\text { Loans, } \\
\text { \% TA }\end{array}$} & All U.S. & 58.63 & 59.45 & 58.62 & 61.52 & 63.16 & 62.73 \\
\hline & Arkansas & 56.53 & 56.90 & 57.06 & 57.89 & 60.60 & 61.06 \\
\hline \multirow{2}{*}{$\begin{array}{l}\text { First Mortgages, } \\
\% \text { TA }\end{array}$} & All U.S. & 15.11 & 15.40 & 14.95 & 15.17 & 15.43 & 13.11 \\
\hline & Arkansas & 15.94 & 16.44 & 16.56 & 16.67 & 17.43 & 17.37 \\
\hline \multirow{2}{*}{$\begin{array}{l}\text { Deposits, } \\
\% \text { TA } \\
\end{array}$} & All U.S. & 85.10 & 84.92 & 84.49 & 83.22 & 83.40 & 83.30 \\
\hline & Arkansas & 87.23 & 86.35 & 86.12 & 85.33 & 83.71 & 84.44 \\
\hline \multirow{2}{*}{$\begin{array}{l}\text { Equity, } \\
\text { \% TA }\end{array}$} & All U.S. & 9.94 & 10.11 & 10.06 & 9.83 & 10.03 & 10.02 \\
\hline & Arkansas & 10.35 & 10.87 & 10.98 & 10.64 & 10.99 & 10.65 \\
\hline \multirow{2}{*}{$\begin{array}{l}\text { Return on } \\
\text { Assets (\%) }\end{array}$} & All U.S. & 1.19 & 1.22 & 1.19 & 1.16 & 1.13 & 1.04 \\
\hline & Arkansas & 1.21 & 1.11 & 1.01 & 0.95 & 0.79 & 0.88 \\
\hline
\end{tabular}

\section{ARE BANKS WITH ADVANCES DIFFERENT?}

Using FHLB advances makes it possible for banks to grow more rapidly than deposit growth alone allows. If a bank is faced with increasing loan demand from good quality borrowers, the advances are potentially "life saving" in that they allow the bank to book good credits and enhance profitability. ${ }^{4}$ However, rapid growth often comes from expanding loan quantity at the expense of loan quality, and these poorer loans will later result in more credit problems for the bank. Because FHLB advances are secured by the best loans in the portfolio, there is no risk pricing on the advanced funds. This arrangement insulates the bank from any market pressures that might constrain additional risk through higher rates on other types of borrowed funds.

These points suggest a direction for examining community banks using advances. Call report data for all Arkansas banks from 1996 to 2001 yields information for evaluating loan and deposit growth rates, as well as composition of the banks' loan portfolios. Tests of differences in these values between advance- and non-advanceusing banks, along with many other key performance ratios, show just how "different" the FHLB borrowers are. Table 2 contains the results of these tests.

Before examining financial characteristics, it is useful to highlight any organizational or location differences in the advance and non-advance using banks. As Table 1 shows, Arkansas banks are slightly more likely to be organized in bank holding companies than the national average community bank. Table 2 reports results that show there is a significantly greater proportion of advance using banks that are in holding companies. Also, while Arkansas banks are less likely to be in MSAs, the proportion of advance users in MSAs is somewhat larger than that of nonusers, though the difference is not consistently significant.

For both advance users and non-users, loan growth exceeded deposit growth in every year, and as expected, those banks using FHLB advances experienced consistently faster loan growth than their non-advance peers. However, they also grew deposits at a faster rate. This result may be driven by the slightly higher proportion of advance-using banks in MSAs. More telling than the growth rates are the differences in the composition of the banks' balance sheets. Not only did FHLB borrowing banks grow loans faster, they also have a significantly larger portion of their assets in loans. Those banks also had fewer dollars of assets funded by deposits. While the numbers on deposits appear similar, consider the following: if a bank has $\$ 250$ million in assets, the $2.78 \%$ difference in 2001 represents $\$ 6,950,000$ in deposits. 
Table 2:

t-Test of Differences in Means of Key Balance Sheet Measures Non-FHLB Borrowers versus FHLB Borrowers

\begin{tabular}{|c|c|c|c|c|c|c|c|}
\hline & & 1996 & 1997 & 1998 & 1999 & 2000 & 2001 \\
\hline \multirow{2}{*}{ Number } & Non-FHLB & 170 & 148 & 118 & 91 & 77 & 73 \\
\hline & FHLB & 63 & 77 & 84 & 103 & 107 & 104 \\
\hline \multirow[t]{2}{*}{ BHC (\%) } & Non-FHLB & 87.06 & 85.81 & 86.44 & 83.52 & 79.22 & 80.82 \\
\hline & FHLB & $96.83 * * *$ & $96.10 * * *$ & $95.24 * *$ & $96.12 * * *$ & $96.26^{* * *}$ & $98.08 * * *$ \\
\hline \multirow[t]{2}{*}{ MSA (\%) } & Non-FHLB & 26.47 & 23.65 & 22.03 & 16.48 & 19.48 & 21.92 \\
\hline & FHLB & 31.75 & 33.77 & $33.33^{*}$ & $36.89 * * *$ & $35.51 * *$ & 31.73 \\
\hline \multirow{2}{*}{$\begin{array}{l}\text { Loan Growth } \\
\text { Rate }\end{array}$} & Non-FHLB & 13.09 & 11.65 & 19.94 & 16.41 & 18.68 & 7.07 \\
\hline & FHLB & 15.46 & 14.36 & 25.62 & 17.75 & 24.69 & $15.09 * * *$ \\
\hline \multirow{2}{*}{$\begin{array}{l}\text { Deposit Growth } \\
\text { Rate }\end{array}$} & Non-FHLB & 8.87 & 8.96 & 15.70 & 11.24 & 9.41 & 7.42 \\
\hline & FHLB & 13.75 & 10.63 & 21.98 & 15.05 & 16.19 & $14.07 * * *$ \\
\hline \multirow{2}{*}{$\begin{array}{l}\text { Loans to } \\
\text { Total Assets }\end{array}$} & Non-FHLB & 54.54 & 53.89 & 53.41 & 53.29 & 54.77 & 56.66 \\
\hline & FHLB & $61.90 * * *$ & $62.94 * * *$ & $62.20 * * *$ & $61.96 * * *$ & $64.80 * * *$ & $64.76^{* * *}$ \\
\hline \multirow{2}{*}{$\begin{array}{l}\text { Deposits to } \\
\text { Total Assets } \\
\end{array}$} & Non-FHLB & 87.47 & 86.10 & 86.95 & 86.45 & 84.41 & 86.07 \\
\hline & FHLB & $86.59 *$ & $85.46 * *$ & $84.95 * *$ & $84.33 * * *$ & 83.21 & $83.29 * * *$ \\
\hline \multirow{2}{*}{$\begin{array}{l}\text { Jumbo CDs to } \\
\text { Total Assets } \\
\end{array}$} & Non-FHLB & 14.62 & 15.92 & 17.93 & 18.58 & 19.52 & 21.36 \\
\hline & FHLB & 14.24 & 15.02 & $15.87 * * *$ & $16.98 * *$ & $18.03^{*}$ & $18.90 * * *$ \\
\hline \multirow{2}{*}{$\begin{array}{l}\text { 1st Mort. to } \\
\text { Total Assets } \\
\end{array}$} & Non-FHLB & 15.03 & 15.17 & 15.36 & 15.53 & 15.41 & 16.50 \\
\hline & FHLB & $18.38 * * *$ & $18.89 * * *$ & $18.25 * * *$ & $17.67 * *$ & $18.88 * * *$ & 17.99 \\
\hline \multirow{2}{*}{$\begin{array}{l}\text { All Mort. to } \\
\text { Total Assets }\end{array}$} & Non-FHLB & 16.27 & 16.28 & 16.38 & 16.41 & 16.38 & 17.42 \\
\hline & FHLB & $19.76^{* * *}$ & $20.63 * * *$ & $19.97 * * *$ & $18.99 * * *$ & $20.72 * * *$ & $19.87 * *$ \\
\hline \multirow{2}{*}{$\begin{array}{l}\text { Securities to } \\
\text { Total Assets }\end{array}$} & Non-FHLB & 32.11 & 32.32 & 30.61 & 32.29 & 29.84 & 26.69 \\
\hline & FHLB & $28.28 * *$ & $27.62 * * *$ & $26.24 * * *$ & $27.44 * * *$ & $25.47 * *$ & $22.08 * * *$ \\
\hline \multirow{2}{*}{$\begin{array}{l}\text { Non-Performing } \\
\text { Loans to TA }\end{array}$} & Non-FHLB & 0.50 & 0.50 & 0.52 & 0.69 & 0.67 & 0.84 \\
\hline & FHLB & 0.55 & $0.59 *$ & $0.69^{* *}$ & 0.61 & 0.62 & 0.78 \\
\hline \multirow{2}{*}{$\begin{array}{l}\text { Equity to } \\
\text { Total Assets }\end{array}$} & Non-FHLB & 10.91 & 11.78 & 11.81 & 12.05 & 13.62 & 12.40 \\
\hline & FHLB & $8.83 * * *$ & $9.12 * * *$ & $9.80 * * *$ & $9.39 * * *$ & $9.11 * * *$ & $9.43 * * *$ \\
\hline \multirow{2}{*}{$\begin{array}{l}\text { Unused Commitments } \\
\text { To Total Assets }\end{array}$} & Non-FHLB & 5.61 & 5.40 & 5.19 & 5.08 & 5.72 & 5.16 \\
\hline & FHLB & $6.85 * *$ & $7.63 * * *$ & $7.78 * * *$ & $8.21 * * *$ & $8.56 * * *$ & $7.71 * * *$ \\
\hline
\end{tabular}

* Significant at the $10 \%$ level

** Significant at the $5 \%$ level

*** Significant at the $1 \%$ level

Additionally, the composition of the deposits varies for advance users versus non-users. As noted, FHLB advances may allow banks to grow assets while bypassing other markets for borrowed funds, such as jumbo CDs (deposits greater than $\$ 100,000$ ). The data are consistent with this behavior for Arkansas' banks. In every year, the advance-using banks rely less on large deposits than do the non-users - the $2.46 \%$ difference in 2001 represents $\$ 6,150,000$ less in large deposits for a $\$ 250$ million bank. Because these deposits are uninsured, using fewer of them reduces the banks' exposure to risk pricing.

The FHLB secures its advances with collateral - loans in the borrowing bank's portfolio. And up through 2000, those loans were mortgages. Banks using FHLB advances do invest more of their assets in mortgages than their non-advance-using counterparts. This difference is true for first mortgages, as well as home-equity or second mortgage lending. Again, while the numbers look similar, it is instructive to consider the dollar magnitude of the differences. For example, the $4.35 \%$ difference in all mortgages in 2000 represents $\$ 10,875,000$ in additional mortgages for a $\$ 250$ million bank.

Consistent with the differences in the proportion of loans held, FHLB banks hold much smaller portions of their assets in securities. Note that for both types of banks the securities portfolios shrank as loan demand grew. However, the FHLB borrowing banks decreased their securities holdings at a greater rate, exhibiting an almost $22 \%$ decline, from $28.28 \%$ of assets in 1996 to $22.08 \%$ of assets in 2001 . Non-FHLB banks securities fell by about $17 \%$ 
over the same period, to $26.69 \%$ of assets. The reduced levels of securities holdings imply lower levels of liquidity for the banks.

The banks differ also in the equity positions on their balance sheets. In every year the FHLB borrowing banks have strikingly lower capital levels. Additionally, the mean level for the non-advance-using banks increases almost 150 basis points from 1996 to 2001 . However, the average equity level of the advance-using banks increased only sixty basis points during the same period. It may be the case that the banks not using advances actually are carrying too much capital, while the advance users are more appropriately leveraged. In this case, returns to shareholders will be improved by the greater use of borrowings. On the other hand, because the equity position absorbs losses, such as asset write-downs due to loan quality problems, it is like the cushion or buffer standing in front of the deposit insurance fund. So banks with lower capital levels have smaller cushions to absorb any losses - and the data are consistent with the view that riskier banks have sought out FHLB advances for funding. The extent of this risk may be small, at least at present, as the figures on problem loans reveal. There is no significant difference between the advance users and the non-advance users, and in fact in some years the non-FHLB banks have slightly higher problem loan rates.

These results reveal a consistent pattern of balance sheet differences between those banks that use FHLB advances and those that do not. The table also highlights another important difference, but this one is off the balance sheet. In commercial lending as well as the growing home equity lending area, both bank managers and supervisors must consider not just how many dollars are already loaned, but how many dollars are committed to future loans. In every year, those Arkansas banks that use FHLB advances have significantly higher levels of unused commitments than those banks that do not use advances. These unused positions represent loans that may show up in the banks' loan portfolios in the future, adding to loan growth and funding needs.

\section{Modeling FHLB Advance Usage}

The means tests reveal consistent patterns of differences between non-advance-using banks and those with FHLB advances. A more rigorous modeling of the banks' characteristics can reveal which of the differences are significant factors in predicting advance use, while controlling for interactions among variables that is impossible with only means tests. Because the result of interest is advance usage or not, a logistic regression rather than OLS is appropriate. The prior discussion suggests the following model:

Probability (Advance user, $\mathrm{y}=1)=\mathrm{f}($ LOANRATIO, PROBLOAN, CDDEPEND, EQRATIO, MTGRATIO, COMRATIO, ROA, LOGSIZE, BRKRDUM, MSADUM, BHCDUM)

LOANRATIO is net loans and leases as a percent of total assets; a high value should increase the probability of advance use. PROBLOAN is past due and non-accrual loans as a percent of assets; it is possible that banks with more problems seek out more non-risk-priced FHLB advances which means higher values increase the probability of advance use. CDDEPEND is the ratio of jumbo CDs to total deposits; banks that can more easily fund assets with CDs are less likely to need advances, so this variable should have a negative effect on the probability. EQRATIO is the book value of equity as a percent of total assets; higher values reduce the need for advance funding. MGTRATIO measures all residential mortgages as a percent of total assets; higher values should increase the probability of advance use. COMRATIO is the total level of unused commitments, commercial and consumer, as a percent of total assets; since these represent future funding needs, higher values should increase the probability of using advances. The remainder are control variables - ROA is return on assets (net income divided by total assets), LOGSIZE is the natural $\log$ of total assets, BRKRDUM is a dummy variable that equals 1 if any of the bank's CDs are brokered, MSADUM equals 1 if the bank is located in a MSA, and BHCDUM equals 1 if the bank is organized in a bank holding company.

Table 3 reports the results of the estimation. The coefficients are jointly significant, and the model produces 81 percent concordance in predicted versus actual values of advance use. LOANRATIO and EQRATIO both enter with large coefficients with the predicted signs and are highly significant. MGTRATIO and COMRATIO have smaller effects on the probability of advance use, but the signs are as predicted and are also significant. Neither PROBLOAN nor the deposit variables CDDEPEND and BRKRDUM are significant. Of the control variables, 
LOGSIZE and MSA are significant; size has a slightly positive effect on the probability, while being in a MSA slightly reduces the probability. These results suggest community banks with large (as a percent of assets) loan portfolios, higher levels of mortgages, lower equity, and large commitments for future lending are very likely to seek out FHLB advances.

Table 3:

Logistic Regression Results Estimating Probability that Bank Uses FHLB Advances

\begin{tabular}{|c|c|c|}
\hline Variable & Model One & Model Two \\
\hline Intercept & -13.9252 & 44.1424 \\
\hline Standard Error & 1.3879 & 4.8588 \\
\hline Pr $>$ ChiSq & $<0.0001$ & $<0.0001$ \\
\hline \multirow{3}{*}{ Loans/Total Assets } & 3.9082 & 4.5584 \\
\hline & 0.8610 & 1.0259 \\
\hline & $<0.0001$ & $<0.0001$ \\
\hline \multirow{3}{*}{ Problem Loans/Total Assets } & 7.8252 & 13.7207 \\
\hline & 12.1196 & 14.9240 \\
\hline & 0.5185 & 0.3579 \\
\hline \multirow{3}{*}{ Jumbo CDs/Deposits } & 1.0736 & \\
\hline & 0.9972 & \\
\hline & 0.2816 & \\
\hline \multirow{3}{*}{ Deposits/Total Assets } & & -57.2473 \\
\hline & & 4.7268 \\
\hline & & $<0.0001$ \\
\hline \multirow{3}{*}{ Equity/Total Assets } & -13.7726 & -68.9858 \\
\hline & 2.7568 & 5.83007 \\
\hline & $<0.0001$ & $<0.0001$ \\
\hline \multirow{3}{*}{ Mortgages/Total Assets } & 2.3884 & 1.3879 \\
\hline & 1.1388 & 1.3240 \\
\hline & 0.0360 & 0.3076 \\
\hline \multirow{3}{*}{ Commitments/Total Assets } & 5.9346 & -2.3927 \\
\hline & 1.8935 & 2.2607 \\
\hline & 0.0017 & 0.2945 \\
\hline \multirow{3}{*}{ ROA } & -5.0266 & 11.9436 \\
\hline & 3.5978 & 14.3834 \\
\hline & 0.1624 & 0.4063 \\
\hline \multirow{3}{*}{ Size $(\log \mathbf{T A})$} & 1.0070 & 0.8328 \\
\hline & 0.1091 & 0.1267 \\
\hline & $<0.0001$ & $<0.0001$ \\
\hline \multirow{3}{*}{ Brokered Deposits Dummy } & -0.0000004 & \\
\hline & 0.0000008 & \\
\hline & 0.6150 & \\
\hline \multirow{3}{*}{ MSA Dummy } & -0.3996 & -0.6351 \\
\hline & 0.1770 & 0.2169 \\
\hline & 0.0240 & 0.0034 \\
\hline \multirow{3}{*}{ BHC Dummy } & 0.3662 & 0.0182 \\
\hline & 0.3185 & 0.3603 \\
\hline & 0.2502 & 0.9596 \\
\hline Likelihood Ratio (Probability > & 339.2395 & 634.1280 \\
\hline Chi Squared) & $<0.0001$ & $<0.0001$ \\
\hline Concordant Pairs (\%) & 81.0 & 90.9 \\
\hline Number of Observations & 1126 & 1126 \\
\hline
\end{tabular}

The lack of significance of CDDEPEND and BRKRDUM suggests an alternative modeling. A second estimation uses the simple ratio of deposits to assets, DEPRATIO; a higher value of this variable should reduce the probability of using advances. This model results in a better fit as seen in the nearly doubled log likelihood ratio and 
higher level of concordance. LOANRATIO and EQRATIO remain large, highly significant factors, and now the DEPRATIO coefficient is also large and significant, with the predicted negative sign. However, MTGRATIO and COMRATIO are no longer significant predictors of FHLB advance use. This estimation suggests that large loan portfolios coupled with low deposit and equity funding are the keys that push banks to use FHLB advances.

\section{Are These Differences Risky?}

The analysis of balance sheet and off-balance-sheet characteristics reveals key differences between banks using advances versus non-users. However, these results do not clearly reveal any patterns that suggest reason for concern. Recall that FHLB advances create three potential problems: (1) asset growth more rapid than deposit growth would support, (2) increased risk without the imposition of risk pricing, and (3) increased costs to the FDIC in failure resolutions. The previous section demonstrates clearly that (1) does in fact occur. But it is not apparent that this growth creates too much risk, or that these banks are creating the potential for greater FDIC losses.

To address the questions of increased risk among advance using banks, one must consider the "tails of the distribution" rather than the averages. That is, what is the capital level of the worst set of banks? Or, what is the nonperforming loan rate at the banks with the most problem loans? Then, with these levels as boundaries, evaluate how many of the FHLB banks fall into those categories. The results are alarming. Table 4 contains the results of quartile breakdowns on equity and non-performing loans as percents of total assets. For equity, the problem arises if capital is too low. For each year the $25^{\text {th }}$ percentile, or level of capital that twenty-five percent of the banks fall below, serves as the cutoff. Note that the number of FHLB banks falling in this bottom tier rises from 23 of 63 users in 1996 to 39 of 104 in 2001. The more significant measure is the proportion the FHLB banks represent of the total number in the quartile. By 2001, almost ninety percent of the banks with the lowest capital positions were advance-using banks.

Table 4:

Concentrations of Risk? Lowest Quartile Equity and Highest Quartile Non-Performing Loans Non-FHLB Borrowers versus FHLB Borrowers

\begin{tabular}{|l|l|c|c|c|c|c|c|}
\hline & & $\mathbf{1 9 9 6}$ & $\mathbf{1 9 9 7}$ & $\mathbf{1 9 9 8}$ & $\mathbf{1 9 9 9}$ & $\mathbf{2 0 0 0}$ & $\mathbf{2 0 0 1}$ \\
\hline & Total Number & 58 & 56 & 50 & 48 & 46 & 44 \\
\hline $\mathbf{2 5}^{\text {th }}$ Percentile & Equity/TA (\%) & 8.15 & 8.39 & 8.56 & 8.12 & 7.91 & 8.22 \\
\hline Number Below & FHLB & 23 & 32 & 33 & 37 & 42 & 39 \\
\hline & \% FHLB & 36.51 & 41.56 & 39.29 & 35.92 & 39.25 & 37.50 \\
\hline & \% Number & 39.66 & 57.14 & 66.00 & 77.08 & 91.30 & 88.64 \\
\hline $\mathbf{7 5}^{\text {th }}$ Percentile & NPL/TA (\%) & 0.67 & 0.67 & 0.74 & 0.86 & 0.91 & 1.07 \\
\hline Number Above & FHLB & 19 & 23 & 25 & 25 & 24 & 25 \\
\hline & \% FHLB & 30.16 & 29.87 & 29.76 & 24.27 & 22.43 & 24.04 \\
\hline & \% Number & 32.76 & 41.07 & 50.00 & 52.08 & 52.17 & 56.82 \\
\hline JOINT Eq/NPL & Total Number & 10 & 15 & 14 & 11 & 11 & 12 \\
\hline & FHLB & 5 & 9 & 10 & 8 & 9 & 10 \\
\hline & \% FHLB & 7.93 & 11.69 & 11.90 & 7.77 & 8.40 & 9.62 \\
\hline & \% Number & 50.0 & 60.0 & 71.4 & 72.7 & 81.8 & 83.3 \\
\hline
\end{tabular}

By itself this low-capital concentration may not be a problem, but when combined with evaluation of the problem loans rate, a clearer picture emerges. Here the concern is with a value that is too high, so the table presents the $75^{\text {th }}$ percentile level as the threshold, or the rate of problem loans that only twenty-five percent of banks exceed. The FHLB advance-users constitute a smaller percent of the total here, but it is still problematic that more than half of the banks with the highest levels of problem loans are advance users and that the trend is increasing. Evaluating the joint incidence of lowest capital and highest problem loans reveals a further concentration among FHLB advance users. The banking industry enjoyed a period of record profitability during the sample period, so it is reasonable that small numbers of banks have both capital levels below the $25^{\text {th }}$ percentile and problem loans above the $75^{\text {th }}$ percentile. However, in every year the proportion of those banks that are also FHLB advance users increases, with 10 of 12 such 
banks in 2001. In absolute numbers these constitute a small portion of the banks in the study, but these are the banks most likely to present supervisory and insurance fund problems in the future.

Even though the CDDEPEND and BRKRDUM coefficients are not significant in predicting advance use, the source of jumbo CD dollars is an area of potentially increased risk. While the advance-using banks rely less on jumbo CDs, a much larger number of them fund those large deposits from brokered sources. Banks may obtain funds in the national deposit market, often from deposit brokers who pool their customers' funds and then shop around for the best rates available. Another aim of these brokered deposits is to obtain FDIC insurance for deposits that otherwise would not carry this benefit. Consequently, the brokered deposits are often issued in $\$ 100,000$ increments, so that each piece of the brokered funds is insured. Additionally, these deposits often are less stable than locally obtained funds, with dollars on deposit today being moved somewhere else tomorrow. Of the 107 advance-using banks in 2000, 42 issued brokered deposits, as did 41 of the 104 users in 2001. These numbers are up from only 17 issuers in 1999 . The number of non-advance banks using brokered deposits held steady at 13 and 12 for the same years. The Federal Reserve System's Commercial Bank Examination Manual (2002) expressly notes that examiners should be concerned about small or medium-sized banks' dependence on funds from sources outside their normal service areas, and the examiners' reports should mention "relevant concerns" when brokered deposits represent 5 percent or more of the bank's deposits. For all Arkansas banks that use brokered deposits, that is, both users and non-users of FHLB advances, the average level of brokered deposits as a percent of deposits exceeds this 5 percent threshold. Alarmingly, the maximum level is for an advance-using bank, with $33 \%$ of its deposits from brokered sources. Thus, while the advance-using banks in Arkansas rely less on jumbo CDs than non-advance users, they are much more likely to tap the national brokered deposit market and seek funds outside their local markets.

\section{CONCLUSION - AND A CAVEAT}

Access to FHLB advances relieved a tremendous funding problem facing banks nationally and in Arkansas. As the economy prospered and loan demand grew, banks faced often sluggish or declining rates of deposit growth. However, it is not yet clear if all the growth followed sound banking practices. The analysis presented here shows that higher levels of loans to assets, and lower levels of deposits and equity (also as a percent of assets) are the key predictors of FHLB advance usage by community banks. Additionally, these banks extend commitments for future lending at a greater rate than banks that do not use the advances. Of particular concern is the concentration of banks using advances among the banks that have the lowest levels of capital and a similar concentration among banks with the highest rates of problem loans. Because Arkansas banks operate in markets that are reflective of community banking nationally, these results inform both the direction of future research and the focus of supervisory scrutiny relative to the use of FHLB advances.

None of this analysis suggests that any of these banks is in imminent danger of failure. Currently banks are facing almost the opposite of the funding gap problem. Loan demand is more sluggish due to the weaker economy, and deposits have flowed back into banks as investors retreat from the stock market. However, these results do suggest that economic weakness is likely to stress some banks a great deal more than it will others, and that some of that stress may come from servicing the debt due the FHLB.

\section{SUGGESTIONS FOR FUTURE RESEARCH}

The analysis and results in this paper offer insights for future research into funding choices and risk-taking behaviors in banking. Specifically, an extension of the basic model to a full, national sample of community banks would directly answer the extent of advance use and what characteristics predict that usage. Also, after the stock market break in 2000, there has been some increase in the flow of deposit dollars back to banks. However, FHLB advances may not always be easily unwound. Additional research exploring the connection between deposit growth, levels of FHLB advances, and the asset-side investments of banks could reveal how advance-using banks chose to use increased deposit dollars. The very low number of bank failures in the most recent past acts to mitigate concern about the actual risk exposures of advance using banks. However, the FHLB enjoys an exemption to absolute priority rules in settling claims after failure which can actually increase the cost to the insurance fund beyond the level of the advance balance. Assessing the potential exposure of the FDIC to costs in failure due to FHLB recoveries is an 
important avenue of future research, given that the results in this paper show that advance usage is concentrated in the banks with the lowest equity positions.

\section{REFERENCES}

1. DeYoung, Robert, William C. Hunter, and Gregory F. Udell, The past, present, and probable future for community banks, Journal of Financial Services Research 25, 85-133, 2004.

2. Federal Reserve Board of Governors, Commercial Bank Examination Manual, Section 3000.1, pp. 4.1-4.2, May 2002.

3. Hall, John R., Thomas B. King, Andrew P. Meyer, and Mark D. Vaughan, Did FDICIA Enhance Market Discipline on Community Banks? in Research in Financial Services: Private and Public Policy, vol. 13 ("Ten Years After Prompt Corrective Actions"), George Kaufman, editor. New York: Elsevier Science, 2002.

4. Hannan, Timothy H. and Robin Prager. The Competitive Implications of Multimarket Bank Branching. Finance and Economics Discussion Series, 2001-43. Washington, Board of Governors of the Federal Reserve System, 2001.

5. Stojanovic, Dusan, Mark D. Vaughan, and Timothy J. Yeager, Is Federal Home Loan Bank Funding a Risky Business for the FDIC? Federal Reserve Bank of St. Louis, Regional Economist, October 2000, pp. 4 - 9.

\section{ENDNOTES}

${ }^{1}$ Stojanovic, Vaughan, and Yeager (2000).

${ }^{2}$ Hall, King, Meyer, and Vaughan (2002) report evidence that the passage of FDICIA increased the sensitivity of banks' jumbo CD rates to bank risk, though the effect is small.

3 These results are for all Arkansas banks, and for each year there are a few banks that exceed the $\$ 500$ million asset cap. However, they still exhibit the characteristics in the Hannan and Prager (2001) and/or DeYoung, Hunter, and Udell (2003) definitions of community banks. For each year, the number of larger banks and the average size (\$000) if they are excluded are: $1996-7, \$ 101,116 ; 1997-6, \$ 101,174 ; 1998-5, \$ 98,874 ; 1999-9, \$ 103,906 ; 2000-7$, $\$ 114,423$; and $2001-8, \$ 123,121$.

${ }^{4}$ FHLB advances, across maturity structures, are almost always less expensive than alternative sources of borrowed funds. Consequently, loans made on FHLB dollars have wider spreads. 


\section{NOTES}

